\title{
Kritik Terhadap Nilai Tradisional Masyarakat Jepang dalam Novel Hanaoka Seishu No Tsuma
}

\author{
Nina Alia Ariefa ${ }^{1}$, Yusy Widarahesty ${ }^{2}$ \\ ${ }^{1}$ Program Studi Bahasa dan Kebudayaan Jepang, Fakultas Ilmu Pengetahuan dan Budaya, \\ Universitas Al Azhar Indonesia, Jl. Sisingamangaraja Kebayoran Baru, Jakarta Selatan, 12110 \\ ${ }^{2}$ Program Studi Ilmu Hubungan Internasional, Fakultas Ilmu Sosial dan Ilmu Politik, \\ Universitas Al Azhar Indonesia, Jl. Sisingamangaraja, Kebayoran Baru, Jakarta Selatan 12110 \\ Penulis untuk Korespondensi/E-mail: nina_alia@yahoo.com
}

\begin{abstract}
Abstrak - Penelitian ini bertujuan untuk menemukan perwujudan nilai tradisional masyarakat Jepang dan kritik terhadapnya melalui penggambaran tokoh dalam novel Hanaoka Seishu no Tsuma. Pendekatan semiotika aspek semantika digunakan dalam analisis penelitian ini melalui pengamatan terhadap tokoh perempuan dan laki-laki dalam novel ini. Kesimpulan dari penelitian ini adalah perwujudan nilai tradisional masyarakat Jepang melalui penggambaran tokoh dalam novel Hanaoka Seishu no Tsuma yang meliputi nilai tradisional masyarakat Jepang mengenai standar kualifikasi perempuan, yang mencakup fisik/tampilan, sifat dan perilaku, usia, produktifitas perempuan.

Abstract - This study aims to find the embodiment of the traditional value of Japanese society and criticism of it through the depiction of characters in the novel Hanaoka Seishu no Tsuma. Semantics aspect semiotics approach is used in the analysis of this research through observations of female and male characters in this novel. The results show that there are traditional values of Japanese society regarding women's qualification standards, which includes physical / appearance, nature and behavior, age, women's productivity.
\end{abstract}

Keywords - Hanaoka Seishu no Tsuma, Novel, Semantics, Semiotics

\section{PENDAHULUAN}

$\mathrm{K}$ arya sastra merupakan hasil imajinasi dan kreativitas seorang pengarang. Pengarang menulis tentang apa saja yang menimbulkan keharuan batinnya, dan mendorong untuk berpikir, mencernakan dan mensublimasikan apa yang dilihat, didengar, dirasakannya, dialaminya, dan akhirnya dia mencipta [1]. Selanjutnya [1] mengemukakan bahwa kreativitas seorang sastrawan adalah kemampuan untuk mengapresiasi manusia dan kehidupannya, pengalaman masyarakatnya, sejarah bangsanya, dan negerinya, lingkungan hidupnya, kebudayaan dan sistem nilai bangsanya baik yang homogen maupun yang beragam. Sastra mencoba mengarah kepada persoalan budaya, mencoba memahami kehidupan, melihat persoalan kehidupan, memberikan makna dan mencari dasar persoalan.

Sastra sebagai karya imajinatif tidak hanya membawa pesan, tetapi juga meninggalkan kesan tersendiri bagi para pembacanya. Selain itu, dalam membaca karya sastra para pembaca akan mendapatkan kesenangan dan kegunaan yang diberikan oleh karya sastra itu yang berupa keindahan dan pengalaman-pengalaman jiwa yang bernilai tinggi, baik secara langsung maupun tidak langsung. Horace menyatakan bahwa hakekat seni itu dulce et utile atau seni itu indah dan berguna [2]. Jadi, karya sastra selain bersifat menghibur juga bermanfaat bagi penikmatnya.

Berkaitan dengan karya sastra, [3] berpendapat bahwa dari sekian banyak ragam sastra, novel merupakan bentuk yang banyak digemari masyarakat. Dapat dikatakan bahwa novel merupakan cabang sastra yang paling populer di dunia, paling banyak dicetak dan paling banyak beredar. Hal ini disebabkan novel mempunyai daya komunikasi yang luas pada masyarakat, di samping mudah untuk dipahami dan dinikmati. 
Novel sebagai karya sastra seperti juga karya sastra yang lainya, membentuk dunia rekaan berdasarkan realitas kehidupan dan fenomena sosial yang ada. Dibandingkan cerita pendek, yang cenderung padat dan langsung pada tujuannya, novel menyuguhkan konten cerita yang lebih luas dan problematika yang lebih kompleks. Pengarang yang mempunyai wewenang dalam menciptakan sebuah dunia otonom kepengarangan, akan berusaha menyembunyikan sesuatu yang akan menjadi penyampaian pesan dari suatu karya naratif yang akan memberikan pengetahuan dan pengalaman kepada pembaca. Hal ini mengakibatkan tema yang diusung oleh pengarang dalam sebuah novel berada dalam wilayah semantis yang tersirat, yang direpresentasikan melalui problematika yang dikemas di dalam novel.

Novel sebagai salah satu karya dibentuk oleh unsurunsur intrinsik dan ekstrinsik. Unsur-unsur interinsik adalah unsur-unsur formal yang membangun sebuah karya sastra dari dalam secara inheren. Unsur-unsur tersebut adalah tema, plot, amanat, perwatakan, latar, dan pusat pengisahan atau sudut pandang. Unsur ekstrinsik adalah unsur yang berada di luar teks yang berpengaruh terhadap teks itu sendiri. Unsur-unsur tersebut antara lain sosiologi, filsafat, psikologi dan biografi pengarang.

Seorang pembaca karya sastra akan lebih mengenal dengan jelas maksud cerita apabila mereka juga mengenal tokoh-tokoh ceritanya. Menurut Abrams tokoh cerita adalah orang yang ditampilkan untuk suatu karya naratif yang oleh pembaca ditafsirkan memiliki kualitas moral dan kecenderungan tertentu seperti yang diekspresikan dalam ucapan dan apa yang dilakukan dalam tindakan [4]. [5] memberikan batasan tentang tokoh (dramatis personal) adalah tokoh rekaan yang memegang peranan di dalam roman atau drama. Sebagai salah satu unsur intrinsik, penokohan memang penting keberadaannya dalam membangun sebuah karya sastra, namun penokohan tidak dapat berdiri sendiri tanpa kehadiran unsur-unsur intrinsik lainnya.

Salah satu novel karya Ariyoshi Sawako yang berjudul Hanaoka Seishu No Tsuma merupakan sebuah novel yang menarik dalam menyuguhkan sebuah dunia otonom yang terbentuk atas kekuasaan seorang pengarang. Novel Hanaoka Seishu No Tsuma banyak mengungkapkan kompleksitas hubungan dalam rumah tangga serta problematika kehidupan yang digambarkan melalui tokohtokohnya. Bahkan, dalam novel ini mengandung pandangan hidup berisikan nilai-nilai tradisi masyarakat Jepang dan memuat kritik sosial yang dapat memberikan suatu pengetahuan yang bersifat universal dan pengalaman kepada pembaca. Pengarang dinilai berhasil menyuguhkan sebuah gagasan mengenai kritik sosial terhadap nilai tradisional masyarakat Jepang melalui konflik tersembunyi yang terjadi di antara para tokohnya. Selain itu, penggambaran atau deskripsi para tokoh dalam novel ini menyiratkan beragam sisi menyangkut nilai-nilai tradisional Jepang serta respon terhadap nilai-nilai tersebut. Oleh karena itu, penelitian ini bermaksud untuk menelaah tokoh yang ditinjau dari semiotika aspek semantika.

Penemuan perwujudan nilai tradisional masyarakat Jepang dan kritik terhadapnya melalui penggambaran tokoh dalam novel Hanaoka Seishu No Tsuma berdasarkan analisis semiotika aspek semantika inilah yang menjadi tujuan dalam penelitian ini, dengan perumusan masalah sebagai berikut:

(1) Bagaimana perwujudan nilai tradisional masyarakat Jepang dan kritik terhadapnya melalui penggambaran tokoh dalam novel Hanaoka Seishu no Tsuma berdasarkan analisis semiotika aspek semantika?

\section{Aspek Semantik dalam Karya Naratif}

Analisis tokoh dan latar diperoleh melalui analisis aspek semantik. Dari analisis itu akan diketahui bagaimana pikiran-pikiran tokoh dan fungsi latar dalam prosa secara keseluruhan. Menurut [6] aspek semantik memiliki beberapa unsur dan dalam aspek semantik terdapat dua hubungan, yaitu hubungan sintagmatik dan hubungan paradigmatik.

Hubungan sintagmatik dipergunakan untuk menelaah struktur teks sastra dengan menekan urutan satuan-satuan makna karya yang dianalisis. Hubungan sintagmatik adalah hubungan yang bersifat linear, hubungan konfigurasi, hubungan kontruksi (Todorov, dalam [7]), bentuk atau susunan. Dalam teks fiksi wujud hubungan itu dapat berupa hubungan kata, peristiwa-peristiwa, atau tokoh. Jadi, bagaimana peristiwa yang satu diikuti oleh peristiwa-peristiwa yang lain yang bersebab akibat, kata-kata saling berhubungan dengan makna penuh, dan tokoh-tokoh membentuk antitese dan gradasi.

Menurut Roland Barthes, unsur-unsur dalam suatu karya naratif disebut memiliki hubungan sintagmatik apabila unsur-unsur dalam suatu karya naratif menunjukkan suatu kausalitas atau 
kontiguitas. Barthes membedakan unsur-unsur tersebut menjadi dua jenis, yaitu:

1. Fungsi utama, yaitu peristiwa-peristiwa yang mempunyai hubungan sebab akibat sehingga membentuk logika narasi.

2. Katalisator, yaitu peristiwa-peristiwa yang mempunyai fungsi melengkapi fungsi utama. [7]

Fungsi utama merupakan tulang punggung cerita, yang memiliki hubungan kronologis dan logis. Sedangkan katalisator merupakan unsur-unsur yang hanya berperan melengkapi. Katalisator hanya dapat memiliki hubungan kronologis saja antara satu dengan lainnya, dan biasanya terdapat pada urutan peristiwa. Barthes [7] mengemukakan bahwa fungsi utama untuk menentukan jalan cerita (plot) dan fungsi katalisator untuk menghubungkan fungsifungsi utama.

Menurut Todorov, dalam [4], bahwa pengurutan suatu cerita mungkin dapat dilakukan berdasarkan urutan temporal atau urutan logis, secara kronologis atau kausalitas. Namun, sejak zaman Yunani klasik, Aristoteles telah mengemukakan bahwa urutan kausalitas lebih penting daripada kronologis, dan berkat kausalitas peristiwa-peristiwa saling berkaitan dan bergerak. Dalam sebuah teks fiksi, keduanya dapat ditemui, yang menurut Forster, urutan kausalitas membentuk plot, sedangkan urutan temporal membentuk cerita.

Adapun hubungan paradigmatik adalah hubungan unsur-unsur dalam karya naratif yang bersifat selektif dan saling melengkapi. Unsur-unsur tersebut adalah:

1. Indeks yaitu yang menyangkut identitas tokoh, sifat, pemikiran, dan peranannya.

2. Informan yaitu keterangan mengenai latar yang terdiri dari ruang dan waktu.

Unsur-unsur yang memiliki hubungan paradigmatik bersifat integratif [8]. Unsur-unsur itu tidak mengacu pada suatu tindakan pelengkap atau suatu akibat. Akan tetapi, unsur-unsur tersebut akan mengacu pada suatu konsep yang kurang lebih menyebar. Walaupun demikian, unsur-unsur tersebut sangat penting bagi makna cerita. Oleh karena itu, unsur tersebut dapat dikatakan mencakup semua indeks, misalnya tentang sifat tokoh, identitasnya, ataupun mengenai suasana.

Dalam paparan di atas, Barthes membagi atau membedakan indeks menjadi dua kategori, yakni (1) indeks utama dan (2) informan [8] Indeks utama menerangkan sifat-sifat tokoh, identitasnya, perasaannya, sifatnya, filsafatnya, dan lain sebagainya. Sedangkan informan menjelaskan tentang waktu dan tempat. Indeks biasanya bersifat implisit sehingga perlu diuraikan, sedangkan informan umumnya dinyatakan secara eksplisit.

Konsep teoritik yang sudah dikemukakan tersebut umumnya memang menjadi titik tolak telaah teks sastra secara struktural. Oleh karena itu, pandangannya terhadap novel sebagai struktur yang koheren tidak jauh berbeda dengan pandanganpandangan yang dikemukakan oleh Wellek dan Warren (1956); Kenney (1966); Stanton (1968); dan Culler (1977) atau Boulton (1977) misalnya.

Kesimpulannya, karena novel merupakan sebuah struktur, untuk memahaminya atau merebut maknanya sebagai tugas utama peneliti atau pembaca [9], perlu dilaksanakan analisis terhadap elemen-elemen konstitutif novel itu. Relasi sintagmatik dan relasi paradigmatik perlu didecoding secara struktural supaya dapat diperoleh kejelasan cerita itu sendiri dan maknanya. Dengan demikian, penelitian dan penempatan karya yang diteliti dapat dilakukan sewajar-wajarnya dengan menghindarkan diri dari like dan dislike sejauhjauhnya dari peneliti.

\section{METODE}

Penelitian ini menggunakan metode penelitian verstehen atau metode pemahaman-interpretatif. Corpus dalam penelitian ini adalah sebuah novel karya Ariyoshi Sawako, seorang novelis perempuan Jepang, yang berjudul Hanaoka Seishu No Tsuma Novel ini terbit di tahun 1972. Yang digunakan dalam penelitian ini adalah novel versi terjemahan bahasa Inggris yang diterjemahkan oleh Wakako Hironaka dan Ann Siller Kostant dengan judul The Doctor's Wife. Novel ini terdiri dari 174 halaman.

Metode penelitian yang akan dilakukan dalam penelitian ini terdiri dari empat langkah. Langkah pertama adalah penentuan objek penelitian, lalu pengumpulan data yang dilakukan dengan teknik baca dan catat, dengan menyajikan butir-butir tinjauan semantika yang berupa identifikasi sintagma dan paradigma cerita dalam novel Hanaoka Seishu no Tsuma dalam kartu data. Kartu data ini dipergunakan mengidentifikasi sintagma dan paradigma cerita.

Langkah penelitian terdiri dari: 1) Pembacaan novel, kemudian identifikasi urutan peristiwa sebagai 
sintagma. Peristiwa-peristiwa itu didaftarkan sejalan dengan linearitas cerita sehingga akan tampak teknik-teknik penceritaan yang dipakai pengarangnya, misalnya progresif ataukah regresif, 2) Setelah identifikasi sintagma cerita selesai, pembacaan dan pengamatan diulangi guna mengidentifikasi indeks utama tokoh dan informan cerita. Tokoh yang diidentifikasi indeksnya terbatas pada tokoh utama dan tokoh bawahan yang memiliki relasi koheren dengan tokoh utama peristiwa, 3) mencatat hasil pembacaan yang berhubungan dengan perwatakan tokoh utama novel ke dalam kartu data yang berhasil dikumpulkan sesuai dengan perwatakan masing-masing tokoh utama.

Langkah selanjutnya yaitu memilah peristiwaperistiwa yang menduduki fungsi-fungsi utama sebagai pembentuk alur cerita, dan yang duduk sebagai katalisator saja. Kemudian, analisis indeks utama dan informan dalam rangka memperoleh kejelasan makna novel secara keseluruhan. Setelah makna dipahami, kemudian dibuat berbagai interpretasi dalam kaitannya dengan dunia sosial budaya yang merupakan konteks karya yang bersangkutan.

Pendekatan semiotika aspek semantika yang digunakan dalam penelitian ini bermaksud mendeskripsikan kelompok hubungan antara unsur yang hadir (in presentia) dan unsur yang tidak hadir (in absentia), yang menjelaskan tentang unsur tertentu yang mengungkapkan unsur yang lain. Langkah terakhir yaitu penarikan kesimpulan.

\section{HASIL DAN PEMBAHASAN}

\section{Urutan Peristiwa dalam Hanaoka Seishu no Tsuma}

Hasil identifikasi urutan peristiwa pada novel ini terdiri dari 153 sintagma.

\section{Indeks Utama dan Informan dalam Hanaoka Seishu no Tsuma}

Pada bagian ini akan diberikan data penelitian yang berkaitan erat dengan relasi paradigmatik cerita, yakni indeks utama dan informan. Dalam kaitan ini, hanya tokoh-tokoh utama dan sejumlah tokoh bawahan yang mendukung cerita secara signifikan saja yang akan dikemukakan indeksnya, yang mencakup identitas, sifat, dan suasana tokoh. Sedangkan informannya, terbatas pada penjelasan waktu dan tempat yang juga memiliki koherensi dengan peristiwa dan tokoh. Dengan demikian, pembahasan dan analisis yang akan dilakukan dan diberikan pada bagian selanjutnya dapat dilakukan secara intensif.

\section{Indeks Utama Tokoh Kae}

1. Anak perempuan dari Imose Sajihei, pimpinan di wilayah Nate yang berstatus tinggi.

2. Memiliki rasa ingin tahu yang tinggi.

3. Mengagumi sosok cantik Otsugi setelah melihatnya secara diam-diam di usia 8 tahun.

4. Mudah terkesan dan cenderung polos.

5. Terampil memasak, dan menjahit.

6. Menguasai etika, membaca dan menulis, dan adat istiadat Jepang yang menjadi warisan leluhur keluarganya.

7. Berbadan sehat dan jarang sakit.

8. Menikah dengan Seishu di usia 21 tahun.

9. Memendam kebencian pada Otsugi setelah Otsugi menunjukkan permusuhannya kepadanya.

\section{Indeks Utama Tokoh Otsugi}

1. Putri dari keluarga Matsumoto, saudagar kaya.

2. Istri dari Naomichi.

3. Terpelajar.

4. Sangat cantik dengan kulit yang putih dan rambut yang hitam mengilat yang tertata rapi.

5. Berpenampilan sangat rapi, anggun, dan elegan meski dalam kesederhanaan.

6. Cerdas dan bijaksana.

7. Pandai bicara.

8. Mahir membawa diri di setiap kondisi.

9. Pemberani.

10. Pandai berstrategi.

11. Sangat memperhatikan anak-anak lelakinya, khususnya anak laki-laki pertamanya, Seishu, dan berambisi dalam menghantarkan Seishu untuk menjemput kesuksesannya.

\section{Indeks Utama Tokoh Seishu}

1. Anak laki-laki pertama dari Naomichi dan Otsugi

2. Berprofesi sebagai dokter

3. Lelaki muda yang bersemangat dan penuh ambisi

4. Cerdas dan tekun

5. Memiliki tanda hitam bulat di lehernya

\section{Indeks Utama Tokoh Naomichi}

1. Suami Otsugi, ayah dari Seishu.

2. Berbeda usia 14 tahun lebih tua dari istrinya, Otsugi.

3. Berprofesi sebagai dokter.

4. Bibirnya tebal, giginya yang tidak beraturan, rambutnya tidak tersisir.

5. Penampilannya sangat berantakan. 
6. Sering omong besar mengenai leluhurnya dan anak lelakinya, Seishu.

7. Menyimpan harapan yang besar terhadap Seishu.

8. Suka minum sake.

\section{Indeks Utama Tokoh Koriku}

1. Adik perempuan kedua dari Seishu

2. Pendiam.

3. Usianya terpaut dua tahun di bawah Okatsu.

4. Rajin.

5. Anak perempuan yang patuh.

6. Pemerhati yang baik

7. Penuh keterusterangan.

\section{Indeks Utama Tokoh Okatsu}

1. Adik perempuan pertama dari Seishu

2. Pendiam.

3. Usianya terpaut setahun di bawah Seishu.

4. Rajin.

5. Anak perempuan yang patuh.

\section{Keterangan (Informasi) tentang waktu}

1. Pagi, siang, sore, malam, musim semi, musim panas, musim gugur, musim dingin, hujan, tahun 1782 ,

2. lalu, kemudian, sekarang, telah, kelak, ketika, pada suatu hari, pada masa paceklik, seusai percobaan, dulu, setelah, dst. yang menunjuk pada penjelasan tentang waktu baik yang bersifat konkret maupun abstrak.

\section{Keterangan (Informasi) tentang tempat}

1. Hirayama, Ichibamura, Kishu, Nate, Chonomachi, kaki gunung Katsuragi, dan seterusnya.

2. Ruang makan, ruang kerja, ruang keluarga, dapur, beranda, halaman depan, halaman belakang, kebun tanaman herbal, kamar tidur, sumur, ruang praktik, dan seterusnya.

3. Lorong, di sana, di sini, di dalam, di luar, di samping, di atas, dan seterusnya.

\footnotetext{
Analisis

Berdasarkan daftar urutan peristiwa yang sudah disajikan di bagian 1 tersebut, tampak bahwa peristiwa-peristiwa yang "pokok" diselingi oleh beberapa peristiwa sorot balik yang berisi peristiwa yang telah dilalui. Hal itu berarti bahwa novel ini tidak hanya mempergunakan alur progresif atau kronologis saja, melainkan juga divariasikan dengan regresif atau flash back. Sorot balik ini ditampilkan melalui lamunan tokoh yang mengenang suatu kejadian yang telah lalu, dan ditampilkan melalui
}

narator yang menceritakan kisah masa lalu dari tokoh.

Berdasarkan daftar urutan peristiwa tersebut, terdapat sorot balik yang secara umum menyangkut dua hal yaitu kisah masa lalu tokoh Otsugi, yang diceritakan oleh narator, dan lamunan tokoh Kae tentang beberapa peristiwa yang terjadi pada hidupnya, di antaranya berkaitan dengan kenangannya saat pertama kali melihat sosok Otsugi, tentang percobaan yang dilakukan oleh Seishu terhadap anjing dan kucing, tentang Okatsu, adik iparnya.

Peristiwa "pokok" pertama itu kemudian diikuti secara susul-menyusul peristiwa berikutnya - seperti tampak dalam daftar urutan peristiwa - dan sambil diselingi oleh peristiwa-peristiwa sorot balik yang sebagian besar sudah dibicarakan di atas. Akan tetapi, walaupun semua peristiwa tersebut telah berhasil diidentifikasi dalam daftar peristiwa, tidak secara otomatis keseluruhan peristiwa itu membentuk alur atau plot cerita. Syarat sebuah rangkaian peristiwa dapat disebut membentuk plot atau alur cerita tidak hanya kronologi yang menunjuk pada pengertian setelah ini kemudian itu saja, melainkan juga harus menunjukkan hubungan kausalitas yang mengarah pada hubungan sebabakibat [10] [11] [12]. Oleh karena itu, yang disebut alur atau plot atau struktur naratif adalah rangkaian peristiwa dalam kronologi tertentu yang memiliki hubungan sebab-akibat. Berdasarkan pada pengertian ini, sebuah novel dapat ditentukan jenis alur atau plotnya: progresif atau regresif, tunggal atau ganda, rapat atau longgar.

Dalam kaitannya dengan penelitian ini, untuk menentukan jenis alur novel ini ditempuh cara analisis relasi sintagmatik yang bermuara pada penentuan fungsi-fungsi utama cerita dan katalisator. Secara garis besar, fungsi-fungsi utama novel ini terbagi dalam 2 kategori besar, yakni fungsi-fungsi utama yang menyangkut tokoh Kae dan fungsi-fungsi utama yang menyangkut tokoh Otsugi. Pada titik-titik tertentu, kedua fungsi utama tersebut bersinggungan satu sama lain dalam rangka mendukung keutuhan cerita secara keseluruhan. Sedangkan peristiwa-peristiwa yang telah berhasil diidentifikasi dan tidak menduduki fungsi-fungsi utama dipandang sebagai katalisator. Berikut ini akan dikemukakan fungsi-fungsi utama cerita, baik mengenai Otsugi dan Kae. 


\section{Fungsi Utama Tokoh Kae}

1. Kae, anak perempuan dari keluarga samurai terpandang, mendapatkan kisah tentang seorang perempuan cantik bernama Otsugi dari pengasuhnya, Tami. Dipenuhi oleh rasa penasarannya, ia ditemani Tami berkunjung secara diam-diam ke Hirayama untuk mematamatai Otsugi. Sejak saat itu Kae sangat mengagumi sosok Otsugi.

2. Kae pertama kali bertatapan secara langsung dengan Otsugi saat pemakaman kakek Kae.

3. Kae bahagia setelah mendengar kabar dirinya dilamar oleh Otsugi untuk dinikahkan dengan Seishu, anak lelakinya, karena ia sangat terobsesi menjadi bagian dari keluarga Otsugi.

4. Kae menikah dengan Seishu.

5. Otsugi menunjukkan perhatiannya kepada Kae yang membuat Kae merasa bahagia.

6. Kae dan Otsugi memiliki hubungan yang erat sebagai menantu perempuan dan mertua.

7. Kae membantu kebutuhan finansial keluarga barunya dengan ikut menenun setelah mengetahui bahwa uang hasil menenun akan dikirimkan ke Seishu di Kyoto untuk menopang studinya.

8. Kae mulai merasakan sikap dingin Otsugi setelah Seishu pulang ke Hirayama dan mulai menyimpan kebencian kepada Otsugi saat Otsugi menyuruh Seishu untuk tidur seorang diri di kamar tanpa Kae.

9. Kae melahirkan anak perempuan dan Otsugi menanggapinya dengan dingin sambil meminta Kae untuk melahirkan anak laki-laki di lain waktu.

10. Kae terlibat persaingan dengan Otsugi yang mengajukan diri sebagai bahan percobaan bagi Seishu.

11. Kae menjadi bahan percobaan selama dua kali dengan ramuan asli racikan Seishu dan berakhir dengan kebutaan.

12. Kae mendapat perhatian penuh dari Seishu karena peristiwa tersebut.

13. Kae hamil dan melahirkan anak laki-laki.

14. Koriku berhasil membongkar 'perang dingin' yang terjadi antara Otsugi dan Kae.

15. Kae berusaha menyangkalnya.

16. Kae merasa tersentak dengan pendapat Koriku tentang kehidupan pernikahan dan tidak dapat melepaskan pikirannya dari perkataan Koriku.

\section{Fungsi Utama Tokoh Otsugi.}

1. Otsugi, anak perempuan saudagar kaya Matsumoto yang cantik dan terpelajar, mengalami sakit kulit yang tidak tersembuhkan.
2. Naomichi datang dan memberikan syarat bahwa ia akan menyembuhkan Otsugi dengan syarat Otsugi dinikahkan dengan dirinya.

3. Otsugi berhasil disembuhkan dan Naomichi menikah dengan Naomichi.

4. Otsugi melahirkan anak lelaki pertamanya, Seishu, dibantu oleh Naomichi, dan memiliki 6 anak lainnya.

5. Naomichi dan Otsugi memiliki harapan besar pada Seishu untuk menjadi dokter terkenal dan menyekolahkan Seishu ke Kyoto untuk menimba ilmu medis.

6. Otsugi datang ke kediaman Kae untuk melamar Kae untuk Seishu.

7. Otsugi menyambut kehadiran Kae dengan hangat selepas pernikahan Kae dan Seishu.

8. Otsugi menyambut niat baik Kae untuk membantu menenun bersama anak-anak perempuannya yang lain.

9. Otsugi bersikap dingin pada Kae setelah kepulangan Seishu ke Hirayama.

10. Kae melahirkan bayi perempuan, namun Otsugi menyambutnya dengan dingin dan meminta agar Kae melahirkan anak laki-laki di lain waktu.

11. Otsugi mengajukan diri sebagai bahan percobaan Seishu agar Seishu dapat menguji cobakan ramuannya kepada manusia, setelah menangkap keinginan Seishu untuk menguji cobakan ramuannya kepada manusia setelah ramuannya berhasil bekerja terhadap anjing dan kucing.

12. Otsugi terlibat perdebatan dengan Kae yang juga ikut mengajukan diri.

13. Otsugi digunakan sebagai bahan percobaan, namun dengan Seishu menggunakan ramuan palsu berupa minuman beralkohol dosis tinggi.

14. Otsugi meminum ramuan itu, dan mengklaim keberhasilan Seishu terhadap dirinya.

15. Otsugi kesal karena Seishu melakukan percobaan kembali menggunakan Kae.

16. Otsugi kesal pada Kae karena menantunya tersebut tidak sadarkan diri selama 3 hari dan membuat khawatir Seishu.

17. Otsugi mendesak Seishu untuk menggunakan tubuhnya kembali untuk percobaan.

18. Otsugi digunakan sebagai bahan percobaan, namun Seishu tetap menggunakan ramuan palsu.

19. Otsugi merasa kecewa karena efek ramuan tersebut tidak membuatnya tertidur selama berhari-hari seperti yang terjadi pada Kae.

20. Otsugi merasa kalah dari Kae karena Kae kehilangan penglihatannya sebagai akibat ramuan percobaan Seishu. 
21. Otsugi meninggal dunia dalam kesedihan tanpa mengetahui Kae bahwa Kae sedang hamil.

Pemahaman fungsi-fungsi utama di atas tidak dapat dipisahkan dari makna novel ini secara keseluruhan karena kepingan-kepingan peristiwa yang simpangsiur yang menyebabkan kesulitan dalam menentukan alur utama novel. Berdasarkan fungsifungsi utama tersebut, diperoleh gambaran mengenai alur utama novel yang secara keseluruhan berkaitan dengan dua tokoh di atas. Kedua fungsi utama tokoh tersebut bersinggungan satu sama lain pada titik-titik tertentu dalam rangka mendukung keutuhan cerita secara keseluruhan. Titik persinggungan tersebut adalah sebagai berikut.

1. Kontak langsung Otsugi dan Kae saat di pemakaman kakek Kae

2. Kae yang terobsesi dengan Otsugi

3. Otsugi menginginkan Kae menjadi menantunya

4. Otsugi dan Kae berinteraksi satu sama lain dengan akrab.

5. Seishu pulang ke Hirayama.

6. Otsugi memusuhi Kae dalam bentuk konflik, yaitu Otsugi menyuruh Seishu tidur sendiri, Kae melahirkan anak perempuan, Otsugi mengajukan diri dalam percobaan Seishu.

7. Kae mengalami kebutaan dan Otsugi merasa kalah dari Kae.

Peristiwa kontak langsung antara tokoh Otsugi dan Kae pada poin 1 menjadi sangat "pokok" bagi keseluruhan cerita novel ini, karena yang menjadi permasalahan utama pada novel ini adalah menyangkut dua tokoh tersebut dalam hubungannya dengan Seishu yang diungkapkan dalam paruh awal cerita itu, dan sejumlah konflik yang timbul karenanya.

Untuk menentukan makna keseluruhan, analisis terhadap relasi paradigmatik juga tidak dapat diabaikan begitu saja. Oleh karena itu, informasi dan indeks utama tokoh perlu dilibatkan dalam hubungan ini. Tokoh utama novel ini adalah Kae. Ia digambarkan sebagai tokoh yang hidup di zaman Edo dengan latar belakang masyarakat feodal. Ia dibesarkan dalam lingkungan keluarga samurai dan dididik oleh ibunya banyak keterampilan rumah tangga. Kutipan berikut ini menjelaskan hal tersebut.

...Kae, anak dari Imose Sajihei asal Ichibamura... Keluarga Imose yang terhormat bertugas sebagai kepala desa dan seorang samurai, dan yang terpenting, bertugas untuk melayani pemimpin tertinggi provinsi Kishu saat ia melintasi wilayah Nate dalam perjalanan menuju Kuil Ise. Sebagai konsekuensi dari posisi mereka yang tinggi, Kae tidak dibesarkan berlarian di lapangan seperti gadis-gadis kelas petani di desa mereka. Tapi meskipun demikian, keluarga Imose merupakan keluarga yang sederhana. Berdasarkan pengalaman pribadinya, ibu Kae memutuskan untuk mengajarkan anak perempuannya hal-hal yang berguna seperti memasak dan menjahit daripada keterampilan yang ...yang biasa dipelajari banyak gadis dari kelasnya. Sebagai tambahan dari tugastugas kerumahtanggaan, Kae mempelajari etika, membaca dan menulis, dan adat istiadat Jepang yang menjadi warisan leluhur keluarganya. Di usia yang ke-14, ia mampu memasak beberapa masakan special yang ia sajikan sendiri untuk penguasa Kishu di atas meja sajian yang berhias lambang keluarga Kae. Kedua orang tuanya sangat bangga kepadanya. (hal 6)

Ia adalah gadis yang penuh rasa ingin tahu dan berbadan sehat. Pengetahuannya tentang Otsugi diperolehnya melalui pengasuhnya yang bercerita tentang seorang perempuan cantik dan penampilannya yang memesona yang tinggal di Hirayama yang bernama Otsugi. Otsugi menjadi bahan perbincangan masyarakat luas, sehingga Kae menjadi penasaran dengan sosok Otsugi. Setelah ia melihat dengan mata kepalanya sendiri, Kae menjadi pengagum Otsugi dan terobsesi dengannya.

Tokoh Otsugi digambarkan sebagai perempuan yang sangat cantik, dengan penampilan yang sempurna. Berikut ini adalah kutipannya.

Meski di hari yang sangat panas, ia berpakaian rapi dalam kimono bergaris tipis dan obi yang terikat ketat di pinggangnya. Yang sangat mengesankan adalah kulitnya, yang seputih susu seperti bunga terong, dan rambutnya yang berkilau, yang ditata dengan apik dengan tatanan tinggi. ... alisnya yang tercukur rapi seperti mempelai perempuan dan rambut yang hitam legam yang menonjolkan penampilan Otsugi yang sangat lembut. (hal 5)

Ia anak perempuan dari keluarga Matsumoto, saudagar kaya pencelupan benang. Fisiknya yang sempurna, penampilan dan gerak geriknya yang anggun membuat banyak orang kagum padanya dan ia selalu menjadi pusat perhatian masyarakat tiap kali ia berada di wilayah publik, seperti saat ia melayat pada acara pemakaman kakek Kae.

Apakah Otsugi menyadari semua pasang mata tertuju padanya? Tidak disangkal, kekaguman dan perhatian semuanya tertuju pada kecantikan dan 
tampilan mudanya. Meskipun kepalanya tertunduk dalam rasa sungkan, punggungnya tetap tegak, dan ia tampaknya benar-benar sadar dengan orangorang di sekitarnya. (hal 12-13)

Pandangan dirinya mengenai tanggung jawab seorang perempuan dalam keluarga tersurat dalam dialog Otsugi berikut ini.

"Aku katakan ini padamu karena aku menyadari bahwa aku tidaklah cukup tepat dengan peranku. Aku tahu, aku dibesarkan di antara para petani, pedagang dan seniman. Suamiku belajar metode medis Barat terbaik, dan memang ia belum banyak menghasilkan. Sampai hari ini aku terus berusaha. Tetapi total dedikasi bukanlah segalanya. Akhir musim semi lalu Umpei berangkat menuju Kyoto untuk mendapatkan pelatihan medis. Dalam tiga tahun ia akan kembali. Aku merasa, sebagai ibunya, aku harus menemukan perempuan yang tepat untuknya, seseorang yang dapat mendorongnya untuk berkembang dan menjadi dokter yang baik. Aku berhutang banyak pada keluarga Hanaoka karena aku tidaklah sesuai dengan harapan mereka." (hal 18)

Banyaknya penggambaran mengenai sosok Otsugi serta kesan yang diungkapkan oleh banyak tokoh mengenai Otsugi sebagai sosok perempuan yang dikagumi oleh banyak orang, menunjukkan bahwa tokoh ini mewakili gambaran sosok perempuan yang ideal di zaman Edo, sesuai dengan latar belakang novel ini. Di sisi lain, tokoh Kae digambarkan menjadi tokoh perempuan yang berusaha menyejajarkan diri dengan 'keunggulan' yang dimiliki oleh tokoh Otsugi yang digambarkan melalui banyak peristiwa, terutama saat Seishu telah kembali ke Hirayama, seperti yang telah dipaparkan dalam urutan peristiwa di atas. Melalui kedua tokoh ini, pembaca diberikan penggambaran secara tidak langsung mengenai penentuan standar perempuan di mata masyarakat.

Sikap dan tindakan para tokoh perempuan, serta pujian dan komentar yang diperoleh oleh tokoh perempuan dalam novel ini merupakan 'penanda' yang kemudian kita analisis untuk dapat memperoleh makna atau 'petanda'-nya. Dari beberapa kutipan mengenai sikap/tindakan tokoh perempuan, lintasan pikiran, suasana batin, serta pujian/komentar yang diperoleh tokoh perempuan, diperoleh suatu informasi mengenai 'kadar/nilai' seorang perempuan yang berlaku di masyarakat yang menjadi latar novel ini. Kutipannya adalah sebagai berikut.
"Tidak hanya cantik, tetapi ia juga cerdas dan bijaksana. Aku tidak mengenalnya dengan baik untuk menilai kecerdasannya, tapi orang-orang menilainya dengan sangat tinggi." (hal 5)

Fisik Otsugi yang cantik dinyatakan melalui kutipan di atas. Dari penampilan fisik serta sikap Otsugi tersebut ia banyak mendapat pujian dan kekaguman dari orang-orang di sekitarnya. Otsugi juga digambarkan selalu merawat tubuh dan menjaga penampilannya dalam setiap aktivitasnya, seperti yang tergambar melalui kutipan di bawah ini.

Tak lama kemudian, Kae menjadi sangat tenggelam dalam pola-pola tenunannya sehingga ia benarbenar mengabaikan penampilan dirinya. Di sisi lain, Otsugi, yang selalu tampil berpakaian rapi, menyapu dengan anggun, dan percaya diri, menampilkan gerak tubuh dan perilaku yang sempurna seperti penari agung dalam drama Noh...Semakin ia (Kae) mengamati Otsugi dalam mengatur penampilannya, semakin ia mengaguminya, dan menyadari bahwa usaha Otsugi yang demikian tersebut benar-benar di luar jangkauan kemampuan Kae. (hal 43)

Pernikahan Otsugi dengan Naomichi membuatnya semakin dikagumi karena meskipun ia berasal dari keluarga kaya, ia tidak mengeluhkan kemiskinan yang ia hadapi dalam keluarga Hanaoka. Berikut ini adalah kutipannya.

"Setiap wanita di sekitar sini tahu dan mengagumi Otsugi, Sudah banyak yang tahu bahwa meskipun keluarganya sendiri kaya, ia tidak mengeluh akan kemiskinan yang dihadapinya sekarang. Dan karena ialah, keluarga Hanaoka disukai soal ini." (hal 23)

Dari kutipan tersebut tampak bahwa nilai penting yang dimiliki oleh seorang perempuan adalah mengenai sikap mulia yang tidak banyak mengeluhkan keadaan. Berikut ini adalah sebuah kutipan yang turut pula mendukung penggambaran mengenai nilai tersebut.

Tetapi meskipun mereka menghadapi kesulitan, keluarga Hanaoka tidak pernah bersikap seperti orang miskin atau menunjukkan kesedihan. Tiap dari mereka merajut harapannya pada Umpei dan kesuksesannya di Kyoto. Rasa optimisme mereka ini dimotivasi oleh ke-rianghati-an dan kecantikan Otsugi. Naomichi, Okatsu, Koriku, dan sekarang Kae ikut bekerja keras, dan bahkan melipatgandakan upaya mereka demi Umpei sebagai bentuk rasa hormat mereka atas 
pengabdian, kepemimpinan dan sikap Otsugi, yang jauh dari celaan. (hal 43)

Sikap Otsugi yang mengajukan dirinya untuk dipakai dalam ekspresimen yang dilakukan Seishu juga menjadi nilai penting lainnya yang berkaitan dengan sikap seorang perempuan, yaitu pengorbanan. Berikut ini adalah kutipannya.

(Sikap) ibu sang dokter yang pemberani ditanggapi dengan penghormatan dan penghargaan. (hal 121)

Otsugi merasa bangga mendapatkan pujian dari orang-orang di sekitarnya atas keberaniannya menjadi kelinci percobaan dalam percobaan putranya, untuk membantu Seishu dalam mencapai cita-citanya. Dalam urutan peristiwa yang telah dipaparkan di atas, Kae pun mengajukan dirinya sebagai bahan percobaan bagi Seishu, sehingga keduanya mendapatkan banyak pujian dan kekaguman. Berikut ini adalah sebagian kutipan dari orang yang memuji tindakan Otsugi dan Kae.

"Benarkah? Itu luar biasa! Benar-benar sangat menakjubkan. Mereka berdua adalah perempuan panutan. Keduanya telah membahayakan nyawanya masing-masing untuk membantu dokter untuk meraih impiannya." (hal 129)

Selain dari masyarakat sekitar, di bagian akhir novel ini, Seishu juga memberikan pujian terhadap ibu dan istrinya. Berikut ini adalah kutipannya.

Menjelang akhir bulan, akhirnya Seishu mengunjungi istrinya. "Kau pasti sudah mendengar tentang kesuksesanku yang luar biasa, kae. Semua ini bisa terwujud berkatmu dan Ibu. Dalam waktu dekat, semua dokter di Jepang akan tercengang dengan pencapaian ini." Ia meneteskan air mata kebahagiaan. Meskipun ia berusaha menguasai dirinya untuk tidak membanggakannya di depan para siswanya, namun ia tidak dapat menutupinya di hadapan Kae. (hal 168)

Satu kutipan dari dialog Okatsu berikut ini juga menambah deret makna tentang nilai pengorbanan pada tokoh perempuan.

"Maka belah dadaku ini. Kalaupun aku mati, aku tetap akan merasa puas mengetahui bahwa aku bisa berguna bagimu." (hal 94)

Pentingnya perempuan untuk dapat hamil, melahirkan bayi yang sehat, dan memiliki anak lakilaki sebagai penerus keluarga juga menjadi sorotan dalam novel ini. Hal ini terlihat saat Kae 'hanya' berhasil melahirkan anak perempuan, dan Otsugi menanggapi kelahiran cucu perempuannya dengan sikap dingin serta meminta Kae agar melahirkan anak laki-laki di lain waktu. Berikut ini adalah kutipannya.

“...Bayi ini milik keluarga Hanaoka, dan mungkin saja menjadi pewaris keluarga kami. Jadi sudah menjadi tugasmu untuk melahirkan bayi yang sehat. Anggap makanan-makanan ini sebagai pemenuhan kebutuhan gizi bayimu. Tolonglah, aku memerintahkanmu untuk makan semuanya dengan berkat dari semua." (hal 77)

"Terima kasih atas kerja kerasmu, Kae. Tolong berikan kami bayi laki-laki lain kali, ya?” (hal 89)

Dari beberapa kutipan berikut ini, kita dapat memperoleh pemahaman tentang rentang usia 'terbaik' bagi seorang perempuan untuk menikah. Dan penggambaran tentang kekhawatiran akan terlampauinya rentang usia bagi perempuan dan atas lamaran yang tidak kunjung datang direntang usia 'terbaik' tersebut.

...terlebih karena Kae telah melampaui masa terbaiknya, dan ia (ayahnya) telah menolak lamaran yang lain karena tidak ada satupun dari lamaran tersebut yang sangat memuaskan. (hal 20)

“...Siapa yang yakin apa yang akan terjadi dalam rentang waktu tersebut? Dan apabila benar ia kembali dalam tiga tahun, apa kamu tidak sadar berapa usia Kae saat itu? 24 tahun!' (hal 25)

Selain kutipan mengenai tokoh Kae terkait pernikahan, terdapat beberapa kutipan lainnya menyangkut tokoh bawahan, yaitu Okatsu, Koriku dan adik-adik perempuan Seishu lainnya, yang menyiratkan mengenai hal ini.

Dia (Okatsu) berusia 30 tahun dan masih melajang. Pada tahun-tahun itu saat ia mungkin menemukan pendamping, ia bekerja di depan mesin tenun dan menyumbangkan tiap sen untuk pendidikan saudara laki-lakinya, uang yang sedianya bisa ia sisihkan untuk hari pernikahannya. Keberuntungannya tidak berubah juga saat kakak lelakinya pulang. Lima tahun dalam keadaan paceklik, saat di mana tidak satu keluarga pun yang dapat membayar apapun selain biaya pemakaman. Oleh karenanya ia tidak mendapat satu pun lamaran. Jikapun ia bisa, Okatsu merasa sulit untuk menerimanya karena seluruh anggota perempuan keluarga Hanaoka harus bekerja keras untuk mengumpulkan uang untuk obat-obatan Seishu yang mahal. Dan jikapun 
Okatsu bersikukuh untuk menikah, ia mungkin saja dapat melakukannya tetapi tanpa mas kawin dan pakaian baru. Masa mudanya, seperti juga Koriku yang berusia 28 tahun, telah dipersembahkan untuk karir kakak lelakinya. (hal 92)

Koriku telah menyerah akan harapan memiliki keluarganya sendiri, tetapi dua adik perempuan termudanya masuk usia pernikahan. Meskipun keadaan financial mereka mengalami kemajuan dibandingan tahun-tahun terakhir, keluarga Hanaoka tetap harus berhemat untuk membayar biaya pernikahan yang terjadi hampir secara berdekatan. (hal 102)

Memikirkan ketidakberuntungan yang dialami oleh anak perempuan tertuanya, Otsugi berusaha memastikan nasib yang lebih baik baik anak-anak perempuannya yang lain, sehingga ia langsung menerima dua lamaran yang datang kepadanya. (hal 102)

Dari ketiga kutipan di atas diperoleh informasi mengenai pernikahan yang terjadi di usia terbaik perempuan menjadi nilai yang 'baik' dan ketidakberuntungan bagi perempuan yang terlambat menikah, terlebih bagi yang 'tidak berhasil' menikah, maka nilainya sebagai perempuan menjadi rendah.

Dengan pembahasan di atas, dapat ditarik benang merah bahwa dari analisis terhadap tokoh, yang penandanya mengacu pada kutipan-kutipan dialog tokoh, gumamam batin atau lintasan pikiran tokoh, penjelasan narrator mengenai penokohan, diperoleh informasi mengenai hal-hal berikut ini:

1. Penampilan fisik

2. Sifat dan perilaku yang perlu disandang seorang perempuan (sikap diam dan tidak mengumbar perasaaan pribadi, tidak banyak mengeluh, patuh, bertanggung jawab, pekerja keras, bermanfaat bagi keluarga, penuh pengorbanan, hidup sederhana, mengabdi pada ibu mertua)

3. Menikah di usia terbaik.

4. Mampu melahirkan anak laki-laki sebagai penerus keluarga.

Keempat aspek tersebut tampak menonjol dalam novel ini, yang kesemuanya mengarah pada pembahasan tentang hakikat seorang perempuan berdasarkan nilai tradisional Jepang. Hampir semua tokoh perempuan dalam novel ini menghadapi kehidupannya masing-masing dalam perannya sebagai seorang perempuan dengan beragam kedudukan dalam keluarga. Tokoh Kae dan Otsugi menggambarkan tentang dua perempuan yang memperjuangkan keberhasilan mereka dalam pelaksanaan peran mereka dalam keluarga dalam kedudukan yang berbeda (sebagai anak perempuan, sebagai istri/menantu perempuan, sebagai ibu/ibu mertua). Begitu pula dengan beberapa tokoh perempuan bawahan lainnya, Okatsu, Koriku, adikadik perempuan Seishu lainnya. Hal ini menandai bahwa novel ini mengungkapkan makna yang terkait erat dengan masalah' hidup menjadi seorang perempuan'.

Berdasarkan analisis tersebut pula dapat diperoleh pemahaman bahwa novel ini mengungkapkan tentang kehidupan perempuan yang sibuk mengejar label sebagai 'perempuan yang berhasil' berdasarkan standar tradisional, dan mengabaikan kebahagiaan sejatinya. Hal ini diperkuat dengan kutipan berikut.

Dalam hatinya, bagaimanapun juga, ia merasa malu. Ia tidak percaya bahwa ia benar-bear telah berguna untuk suaminya atau turut berkontribusi dalam kesuksesannyaa seperti yang Seishu sampaikan. "Selamat. Pasti Ibu juga bahagia!" Ia dipenuhi kesadaran penuh, dan dengan tiap kata yang terucap ia merasa mendapat kritikan dari mendiang adik ipar perempuannya. (hal 168)

Kutipan tersebut di atas lebih menjelaskan makna keseluruhan novel ini.

\section{KESIMPULAN}

Simpulan mengenai perwujudan nilai tradisional masyarakat Jepang melalui penggambaran tokoh dalam novel Hanaoka Seishu No Tsuma yang meliputi nilai tradisional masyarakat Jepang mengenai standar kualifikasi perempuan, yang mencakup fisik/tampilan, sifat dan perilaku, usia, produktifitas perempuan.

Standar kualifikasi perempuan tersebut mencakup tentang kemampuan perempuan yang mampu menjaga fisik dan memelihara penampilannya dengan penampilan yang sesuai dengan posisinya dalam masyarakat, kemampuan perempuan dalam menyandang sifat dan berperilaku 'baik, nilai keutamaan/ke-berharga-an perempuan yang 'berhasil' menikah di usia yang terbaik sesuai dengan standar yang berlaku secara umum di masyarakat, produktifitas perempuan yang dikaitkan dengan kemanfaatan perempuan bagi keluarganya serta kemampuannya menghasilkan keturunan lakilaki bagi keluarganya. Perwujudan nilai tradisional 
masyarakat Jepang tersebut muncul pada tokohtokoh perempuan dalam novel ini yaitu tokoh Kae, Otsugi, Koriku dan Okatsu.

Kritik terhadap nilai-nilai tradisional tersebut muncul melalui sudut pandang tokoh Koriku yang ditujukan kepada Kae mengenai hakikat perempuan dan kehidupan perempuan khususnya dalam dunia pernikahan. Kritik ini muncul sebagai hasil kontemplasinya terhadap kehidupan pribadinya dan kehidupan Okatsu serta dari hasil pengamatannya terhadap kehidupan Kae dan Otsugi dalam hubungannya dengan tokoh Seishu.

\section{UCAPAN TERIMA KASIH}

Ucapan terima kasih penulis tujukan kepada LP2M Universitas Al Azhar Indonesia (UAI) yang telah memberikan dukungan dalam penelitian ini berupa Research Grant dalam Hibah Internal Penelitian tahun anggaran 2017-2018.

\section{REFERENSI}

[1] M. Lubis, Sastra dan Tekniknya, Jakarta: Yayasan Obor Indonesia, 1996.

[2] R. Wellek and A. Warren, Teori Kesusasteraan, Jakarta: PT Gramedia Pustaka, 1995.

[3] J. Sumardjo, Masyarakat dan Sastra Indonesia, Yogyakarta: Nur Cahya, 1979.
[4] B. Nurgiyanto, Teori Pengkajian Fiksi, Yogyakarta: Gajahmada University Press, 1995.

[5] P. H. M. Sudjiman, Memahami Cerita Rekaan, Jakarta: Gramedia Pustaka, 1984.

[6] O. K. S. Zaimar, Semiotik dan Penerapannya dalam Karya Sastra, Jakarta: Pusat Bahasa, Departemen Pendidikan Nasional, 2008.

[7] B. Nurgiyantoro, Teori Pengkajian Fiksi, Yogyakarta: Gajahmada University Press, 2013.

[8] O. K. S. Zaimar, Hubungan Sintagmatik dan Paradigmatik dalam Tiga Novel Iwan Simatupang, Jakarta: Pusat Pembinaan dan Pengembangan Bahasa, 1979.

[9] A. Teeuw, Pembaca dan Menilai Sastra, Jakarta: Gramedia, 1983.

[10] R. Wellek and A. Warren, Theoryof Literature, New York: A. Harvest Book, 1956.

[11] W. P. Kenny, How to Analyze Fiction, Monarch Press, 1966.

[12] R. Stanton, An Introduction to Fiction, New York: Holt, Rinehart and Wiston, 1968. 